\title{
Archaean chromite-bearing layered complex, high-pressure metamorphism, and low-pressure high-temperature granulite: can they all be cogenetic?
}

\author{
SAJEEV KRISHNAN ${ }^{1}$, VENI SUDARSAN ${ }^{1}$ AND BRIAN F. \\ WINDLEY ${ }^{2}$ \\ ${ }^{1}$ Indian Institute of Science \\ ${ }^{2}$ The University of Leicester \\ Presenting Author: sajeev@iisc.ac.in
}

Archaean ( $>2.5 \mathrm{Ga})$ mafic-ultramafic layered complexes developed in/from magma chambers. It is essential to investigate the crystallization temperature-pressure conditions of these rocks to assess the depth and heat pulses that prevailed during their formation. The relevant Sittampundi Complex in southern India comprises alternating layers of chromitite, anorthosite, and garnet-gabbro.

Sajeev and others (2009) reported retrogressed eclogites from the Sittampundi Complex $\left(\sim 1000^{\circ} \mathrm{C}\right.$ at $\sim 20$ kbar $)$. These retrogressed eclogite-garnet gabbros crystallized at ca. $2.5 \mathrm{Ga}$, overprinted by ca. $2.4 \mathrm{Ga}$ metamorphism. $2.5 \mathrm{Ga}$ was also the formation time of anorthosites and gabbros from Sittampundi (Ram Mohan et al., 2013; He et al., 2020). Apart from garnet gabbro-chromitites, Sittampundi has several sapphirine-bearing granulites, for which previous studies reported lowerpressure/ultrahigh-temperature metamorphism.

It is not known how the eclogite-facies and ultrahightemperature metamorphisms in this region are temporally and tectonically related, and the HP $P-T$ conditions of the layered complexes are not well established. The mineral REE contents of such gabbros are relatively immobile during high-grade metamorphism, hence are assumed to retain their original composition; this is supported by the absence of evidence of remelting. Here we calculated the gabbroic mineral-REE, chemistry-based, thermobarometry $\left(850-1080^{\circ} \mathrm{C}\right.$ at $\left.16-24 \mathrm{kbar}\right)$, which are in close agreement with reported local metamorphic conditions. To confirm the $P-T$ conditions of formation, we estimated the $P-T$ conditions of primary $\mathrm{Cr}$-bearing amphibole within chromitite. To determine the original $P-T$ condition of the parent magma, we used amphibole-liquid thermometry, liquidonly thermometry coupled with amphibole-plagioclase barometry. The results yielded a slightly higher temperature $c a$. $1150{ }^{\circ} \mathrm{C}$ at a pressure around $18 \mathrm{kbar}$ for the chromite layers. The composition of parental magma was estimated from the $\mathrm{Al}_{2} \mathrm{O}_{3}$ content in chromite. The $\mathrm{Al}_{2} \mathrm{O}_{3}$ content of the original melt that was in equilibrium with Sittampundi chromite (equilibrium at 1 bar) was 15.61-15.73 wt \%, suggesting a boninitic liquid. The $\mathrm{Al}_{2} \mathrm{O}_{3}$ content in the liquid vs. chromite indicates a MORB signature.

Our results demonstrate that the magmatic crystallization and the high-pressure metamorphism of the Sittampundi Complex were cogenetic during 2.5-2.4 Ga, and coeval with the lower pressure sapphirine-bearing granulites resulted from a later 